\title{
Thermal conversion of granules from feathers, meat and bone meal and poultry litter to ash with fertilizing properties
}

\author{
Paweł Staroń, Zygmunt Kowalski, Anita Staroń, Marcin Banach \\ Cracow University of Technology, Department of Engineering and Chemical Technology, 24 Warszawska St., 31-155 Cracow, \\ Poland \\ e-mail: pstaron@chemia.pk.edu.pl
}

\begin{abstract}
Recently, the increased consumption of poultry meat in the EU has been observed. Short cycle of poultry meat production allows adjusting the level of production to demand. With the increase in the meat production the amount of generated waste that has to be disposed because they pose a risk to the environment also increases. The work presents the possibility to produce a mixture of feathers, meat-bone meal and poultry litter that can be used for energy purposes (alternative fuel). Moreover, the composition of the ashes after combustion will be similar to phosphorus-potassium fertilizers offered for sale. The resulting granules are characterized by a calorific value in the range $13.1-13.3 \mathrm{kJg}^{-1}$. The ash after its combustion contained $11.33-13.38 \%$ of phosphorous, $4.94-5.67 \%$ of potassium, $31.85-32.69 \%$ of calcium and $2.07-2.51 \%$ of magnesium. Moreover, the ash contained $0.45-0.46 \%$ of iron, $0.10-$ $0.11 \%$ of manganese, $0.11-0.14$ of zinc and $0.02 \%$ of copper. Mineral combusted residue of this type of granules has a low content of heavy metals and can be used as an additive to fertilizers and soil improvers, in order to enrich their composition in valuable macro- and micronutrients.
\end{abstract}

Key words: granules, fertilizers, waste, combustion

\section{Introduction}

Economic development results in an increased demand for agricultural products and livestock farming. Short poultry production cycle enables continuous adaptation of production to demand, making this type of industry an important area of agricultural production. Consumption of poultry meat (broilers, turkeys, ducks) is increasing from year to year, resulting in an increase in its production. In the European Union about 45 million tons of meat in 2011 was produced. At that time, Poland took the fourth place in terms of the production of poultry and pork meat, and was also the seventh producer of beef (Staron et al. 2016). Currently Poland ranks first in the production of poultry meat in the European Union (Eurostat 2016). In the production of poultry sector, products and waste are generated, which contributes to pollution. The main waste products are feathers and poultry litter.

Waste feathers are the main waste formed during production of poultry (Kim et al. 2001). Feathers consist of $90 \%$ keratin and constitute 5-7\% of the total weight of adult chickens (Suntornsuk and Suntornsuk 2003, Costa et al. 2012, Paul et al. 2013). Feathers are discarded in the process of poultry processing and as a waste product contributes to environmental pollution (Grazziotin et al. 2006, Vasileva-Tonkova et al. 2009, Staroń et al. 2013). The development of the poultry industry in the world has led to the generation of more than 4 million tons of waste feathers each year, half of which is formed in the United States. An average size farm in Poland generates about 7 tons of chicken feathers during the year. Annually in Poland 77000 tons of waste is generated (Martinez-Hernandez et al. 2007, Górecki et al. 2010, Korniłłowicz-Kowalska and Bohacz 2010, Zaghloul et al. 2011).

Meat-bone meal (MBM) is produced from non-edible animal products falling within category III of waste (i.e. Lowrisk). These include skin, fur, feathers, horns, hooves, claws, blood and meat and returns of meat products. The typical feedstock for producing MBM consists of $40 \%$ moisture, $20 \%$ fat and the remaining $40 \%$ is itself rendered to MBM. These ratios are however, quite variable. The raw material is sterilized after pretreatment (removal of metallic parts, grinding, mixing) for $30 \mathrm{~min}$ at $133^{\circ} \mathrm{C}$ under a pressure of $0.3 \mathrm{MPa}$. Sterilized product is fed to the dryer, where the moisture evaporation and separation of the fat take place. The remaining part of the fat is secreted on a filter press at a pressure of $1 \mathrm{MPa}$, at a temperature of $90-100^{\circ} \mathrm{C}$. Solid fraction is crushed and sieved (EC 2009, Moutinho et al. 2017).

Poultry litter is mainly bird droppings, litter and small amounts of feathers and feed. One hen produces about 170$175 \mathrm{~g}$ of litter per day, with 20-25\% dry matter. Its composition depends on factors such as changes in the weight of the bird, the type of feed, the amount of given water or productivity of poultry. It is a 62-64 kg of litter produced by one bird on an annual basis. Poultry litter is widely regarded as a natural product that can be used as a fertilizer. 
It has nutrients essential for plant growth, such as nitrogen, phosphorus and potassium, and a plurality of micronutrients. They are both in the form of organic and inorganic compounds. Nitrogen occurring in organic compounds is more stable than in the case of nitrogen occurring in mineral fertilizers. Application of poultry litter in fertilizer is associated with the odor substances which are released during the storage of litter and during the farmland fertilization (Badri et al. 2002, Kelleher et al. 2002, Schröder 2005).

Previous works were focused on application of meat and bone meal as a component of mixtures. McDonnell et al. (2001) obtained pellets from the meat and bone meal and peat, which were combusted in fluidised bed combustor. Skodras et al. (2007) prepared mixtures of meat bone meal and Greek brown coal. They studied the properties of obtained compounds under both pyrolysis and combustion conditions. Kwiatkowski et al. (2013) studied the production of energy from fixed-bed gasification of poultry feathers on an industrial scale. The process was carried out in two stages, the feathers were gasified, and the resulting gas was burned in a separate chamber. The resulting exhaust gases produce steam in the boiler. Junga et al. (2017) presented in their work the possibility of using chicken manure as fuel, burned separately and with bituminous coal. Hussein et al. (2017) used the pyrolysis and gasification of chicken manure using different gasifying media in a laboratory scale using semi-batch reactor in a temperature range of 600 to $1000^{\circ} \mathrm{C}$. Fryda et al. (2006) studied the co-combustion of meat-and-bone meal together with three fuels in a laboratory scale fluidized bed. They used two types of coal and olive bagasse residues.

The aim of the study was to analyze, determine the composition and physico-chemical properties of the granules made from feathers, meat-bone meal and poultry litter. In order to verify the possibility of their use as an alternative energy source and the possibility of using mineral residues after burning as additives to fertilizers and soil improvers designed to enrich them with the necessary elements.

\section{Material and methods}

Waste feathers (F) and poultry litter (PL) from the poultry plant (broiler farm) and meat-bone meal (MBM) produced in rendering plants were raw materials to obtain granules. Factories are located in the Wielkopolska region (Poland). Properties of raw material are shown in Table 1.

Table 1. Content of carbon (C), hydrogen $(\mathrm{H})$, nitrogen $(\mathrm{N})$ elements (in dry matter) and moisture of the test material

\begin{tabular}{cccc}
\hline Elemental analysis (\%) & Feathers & Meat and bone meal & Poultry litter \\
\hline C & 48.21 & 41.30 & 31.94 \\
H & 7.41 & 6.24 & 4.60 \\
N & 13.73 & 8.30 & 2.99 \\
Moisture content (\%) & 54.6 & 4.2 & 13.4 \\
\hline
\end{tabular}

Granulate which is a mixture of feathers, meat-bone meal and poultry litter was studied. Granulate can be used as a source of thermal energy and the resulting ash after burning has a composition that allows to use it for the purpose of fertilizer.

Research aimed at the development of the most preferred composition of granulate consisting of two or three components, which would be characterized by high calorific value, and the high contents of macro- and micronutrients. The two-component system of granulate contained feathers and meat-bone meal or feathers and poultry litter, and ternary system contained feathers, meat-bone meal and poultry litter. An experiment plan for the mixtures was used for the selection of the most favorable composition of mixtures (StatSoft, Inc. 2013). The relative desirability of different output values determines the usability function. The utility values of the dependent variable can vary for a value predicted from 0.0 (undesired) to 1.0 (highly desirable). Experiment plan consisted of a complete plan (the content of all the raw materials from 0 to $100 \%$ ) and plans with restrictions (feathers content was in one case, $\min 40 \%$ in the second $\min 50 \%$ ). 
Simplex-centroid plan belonging to the plans for the mixtures allows restricting the size of the input. Then the plan is created in subdomain (simplex) defined by the constraints.

Matching the response surface to the results was based on the selected model having the form:

$$
y=b_{1} x_{1}+b_{2} x_{2}+b_{3} x_{3}+b_{12} x_{1} x_{2}+b_{13} x_{1} x_{3}+b_{23} x_{2} x_{3}+d_{12} x_{1} x_{2}\left(x_{1}-x_{2}\right)+d_{13} x_{1} x_{3}\left(x_{1}-x_{3}\right)+d_{23} x_{2} x_{3}\left(x_{2}-x_{3}\right)+b_{123} x_{1} x_{2} x_{3}
$$

where:

$\mathrm{y}$ - approximated values of output quantities,

$b_{1}, b_{2}, b_{3}, \cdots, b_{123}, d_{12}, d_{13}, d_{23}$ - predictors of the regression coefficients,

$\mathrm{x}_{1}, \mathrm{x}_{2}, \mathrm{x}_{3}$ - approximated values of input quantities.

Mixtures were prepared from raw materials in the operating state (in state of delivering from the plant). Calorific value, total phosphorus content and other macronutrients in the resulting ash after combustion were the dependent variables characterizing the composition of the granulate.

The results of the analysis (Table 1), which did not have a normal distribution, were normalized by appropriate using mathematical transformations (Mazerski 2000). The data are presented in normalized scale which is helpful when comprising values of variables which do not have normal distribution. Formulas based on which normalized values were calculated are presented in approximation profiles with utility function (Fig. 2).

Granulate was obtained from two- and tree-component mixtures, using a manual tablet press and had defined composition. The resulting granulate were tested for determining the heat of combustion using calorimeter KL$12 \mathrm{Mn}$ Precyzja-Bit Company (Polish Norm 1981). It was then combusted in a stationary electric furnace at $900{ }^{\circ} \mathrm{C}$ for $3 \mathrm{~h}$. Ashes were analyzed in order to determine the elemental composition (using ICP-OES spectrometer), and in addition there was a specified spectrophotometric method for total phosphorus content (Pc). Total phosphorus content (Pc) was determined using a spectrophotometer Nanocolor UV/VIS Macherey-Nagel at a wavelength of 430 $\mathrm{nm}$. In order to determine the total phosphorus in samples, probes were mineralized in a mixture of concentrated acids: nitric acid and hydrochloric acid (3:1) at reflux (Polish Norm 1988). ICP-OES served to analyze the elemental composition of ashes. It was done using the emission spectrometer with inductively coupled plasma OPTIMA 7300 DV by PerkinElmer. The tested materials, approximately $0.2 \mathrm{~g}$, were mineralized using concentrated acids: hydrofluoric (HF), nitric $(\mathrm{V})\left(\mathrm{HNO}_{3}\right)$ and chloric $(\mathrm{VII})\left(\mathrm{HClO}_{4}\right)$ at the boiling point. The first stage of mineralization was carried out with $4 \mathrm{~cm}^{3}$ of HF. After evaporation of acid, $8 \mathrm{~cm}^{3}$ of mixture of $\mathrm{HNO}_{3}$ and $\mathrm{HClO}_{4}(1: 1)$ were added. The last step of mineralization was the addition of $4 \mathrm{~cm}^{3}$ of $\mathrm{HNO}_{3}$ and filtering the solution to flasks and diluted to $50 \mathrm{~cm}^{3}$. Obtained solutions were again respectively diluted to ICP analyze. Results are the mean of triplicates.

The results were subjected to statistical analysis. The resulting equations of the research were visualized in layergraphs in a triangular coordinate system.

\section{Results}

In order to compare the composition of the resulting ash to the composition of phosphorus-potassium fertilizers offered for sale, the content of elements in the ash (phosphorus, potassium, calcium and magnesium) was analyzed. Phosphorus-potassium fertilizers offered for sale differ in composition depending on the manufacturer and application. The nutrient content varies in the range: $12-20 \% \mathrm{P}_{2} \mathrm{O}_{5}, 13-25 \% \mathrm{~K}_{2} \mathrm{O}, 5-13 \% \mathrm{CaO}$ and $4-15 \% \mathrm{MgO}$.

The values of the independent variables and the results of the analysis are summarized in Table 2.

Figure 1 shows a graphical representation of the object of research. 
Table 2. The composition of the mixtures, calorific value, content of macro- and micronutrients in the resulting ashes

\begin{tabular}{|c|c|c|c|c|c|c|c|c|c|c|c|c|}
\hline \multirow{2}{*}{$\begin{array}{l}\text { Sample } \\
\text { No. }\end{array}$} & \multicolumn{3}{|c|}{$\begin{array}{l}\text { Mixture composition } \\
\text { (mass fraction, } w)\end{array}$} & \multirow{2}{*}{$\begin{array}{c}\begin{array}{c}\text { Heat of } \\
\text { combustion } \\
\mathrm{J} \mathrm{g}^{-1}\end{array} \\
\mathrm{Q}\end{array}$} & \multicolumn{8}{|c|}{ Elemental composition of ash (\%) } \\
\hline & $\mathrm{F}$ & MBMM & PL & & Pc & K & $\mathrm{Ca}$ & $\mathrm{Mg}$ & $\mathrm{Fe}$ & $\mathrm{Cu}$ & $\mathrm{Mn}$ & $\mathrm{Zn}$ \\
\hline 1 & 1.00 & 0.00 & 0.00 & 13160 & 17.03 & 9.40 & 16.41 & 3.01 & 0.662 & 0.073 & 0.270 & 0.766 \\
\hline 2 & 0.00 & 1.00 & 0.00 & 17161 & 16.97 & 1.02 & 35.14 & 0.80 & 0.429 & 0.004 & 0.009 & 0.039 \\
\hline 3 & 0.00 & 0.00 & 1.00 & 11799 & 8.14 & 6.84 & 34.38 & 3.09 & 0.472 & 0.013 & 0.141 & 0.023 \\
\hline 4 & 0.50 & 0.50 & 0.00 & 14632 & 16.01 & 2.30 & 33.35 & 1.10 & 0.455 & 0.014 & 0.043 & 0.143 \\
\hline 5 & 0.50 & 0.00 & 0.50 & 13014 & 8.86 & 7.40 & 32.10 & 3.10 & 0.486 & 0.022 & 0.162 & 0.133 \\
\hline 6 & 0.00 & 0.50 & 0.50 & 14542 & 12.72 & 4.15 & 34.36 & 2.02 & 0.453 & 0.009 & 0.076 & 0.032 \\
\hline 7 & 0.67 & 0.17 & 0.17 & 12713 & 13.29 & 5.63 & 30.58 & 2.18 & 0.480 & 0.024 & 0.122 & 0.225 \\
\hline 8 & 0.17 & 0.67 & 0.17 & 15875 & 14.94 & 2.56 & 34.32 & 1.27 & 0.439 & 0.008 & 0.041 & 0.061 \\
\hline 9 & 0.17 & 0.17 & 0.67 & 12991 & 10.42 & 6.09 & 34.17 & 2.64 & 0.451 & 0.012 & 0.114 & 0.050 \\
\hline 10 & 0.33 & 0.33 & 0.33 & 14533 & 12.98 & 4.64 & 32.22 & 2.11 & 0.442 & 0.014 & 0.088 & 0.091 \\
\hline 11 & 0.50 & 0.25 & 0.25 & 13306 & 12.78 & 5.07 & 32.51 & 2.11 & 0.456 & 0.018 & 0.101 & 0.136 \\
\hline 12 & 1.00 & 0.00 & 0.00 & 13160 & 16.34 & 9.49 & 16.09 & 3.00 & 0.623 & 0.074 & 0.271 & 0.814 \\
\hline 13 & 0.75 & 0.00 & 0.25 & 12808 & 11.55 & 7.87 & 28.93 & 3.10 & 0.520 & 0.031 & 0.177 & 0.265 \\
\hline 14 & 0.75 & 0.25 & 0.00 & 13000 & 17.44 & 3.78 & 28.48 & 1.50 & 0.497 & 0.026 & 0.095 & 0.279 \\
\hline 15 & 0.67 & 0.17 & 0.17 & 12713 & 13.02 & 5.63 & 29.51 & 2.27 & 0.480 & 0.025 & 0.117 & 0.227 \\
\hline 16 & 0.50 & 0.50 & 0.00 & 14632 & 16.01 & 2.31 & 33.14 & 1.11 & 0.455 & 0.014 & 0.046 & 0.138 \\
\hline 17 & 0.50 & 0.00 & 0.50 & 13014 & 8.86 & 7.55 & 32.41 & 3.17 & 0.487 & 0.020 & 0.151 & 0.128 \\
\hline 18 & 0.40 & 0.60 & 0.00 & 15531 & 17.17 & 1.96 & 35.00 & 1.01 & 0.449 & 0.011 & 0.034 & 0.110 \\
\hline 19 & 0.60 & 0.20 & 0.20 & 12211 & 13.72 & 5.25 & 31.68 & 2.15 & 0.501 & 0.020 & 0.107 & 0.186 \\
\hline 20 & 1.00 & 0.00 & 0.00 & 13160 & 16.51 & 9.30 & 16.25 & 3.19 & 0.643 & 0.073 & 0.250 & 0.758 \\
\hline 21 & 0.70 & 0.00 & 0.30 & 11981 & 9.98 & 7.91 & 29.20 & 3.16 & 0.503 & 0.028 & 0.179 & 0.245 \\
\hline 22 & 0.40 & 0.30 & 0.30 & 13274 & 13.48 & 4.73 & 32.46 & 2.12 & 0.449 & 0.015 & 0.091 & 0.102 \\
\hline 23 & 0.70 & 0.30 & 0.00 & 13163 & 17.25 & 3.30 & 29.21 & 1.48 & 0.493 & 0.024 & 0.076 & 0.243 \\
\hline 24 & 0.40 & 0.00 & 0.60 & 12257 & 9.09 & 7.14 & 31.49 & 3.16 & 0.500 & 0.019 & 0.152 & 0.101 \\
\hline
\end{tabular}

The presented approximation profile characterizes the system with $50 \%$ share of the mass of feathers and $25 \%$ of the mass fraction of meat and bone meal and $25 \%$ of the mass fraction of poultry litter. This mixture is characterized by the combustion heat of $13.1 \mathrm{kJg}^{-1}$, and the ash after its combustion contains: $13.38 \%$ of phosphorus, $4.94 \%$ of potassium, $31.85 \%$ of calcium and $2.07 \%$ of magnesium. Converting elemental content of macronutrients to oxide forms, the ash contains: $30.65 \%$ of $\mathrm{P}_{2} \mathrm{O}_{5}, 9.5 \%$ of $\mathrm{K}_{2} \mathrm{O}, 44.56 \%$ of $\mathrm{CaO}$ and $3.43 \%$ of $\mathrm{MgO}$. The ash comprises also: $0.46 \%$ of $\mathrm{Fe}, 0.02 \%$ of $\mathrm{Cu}, 0.10 \%$ of $\mathrm{Mn}$ and $0.14 \%$ of $\mathrm{Zn}$.

The ash formed after combustion of mentioned system has a higher content of phosphorus and calcium and less potassium and magnesium, comparing available fertilizer. In order to enrich the resulting ash in potassium and magnesium the fraction of MBM should be reduced by increasing the fraction of poultry litter in the mixture. 
a)

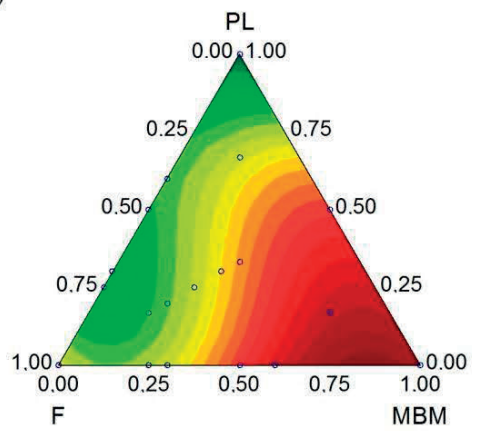

c)

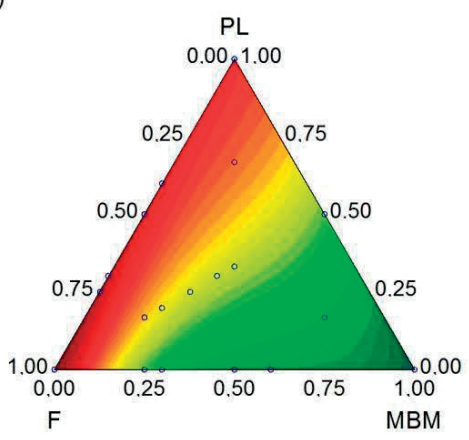

e)

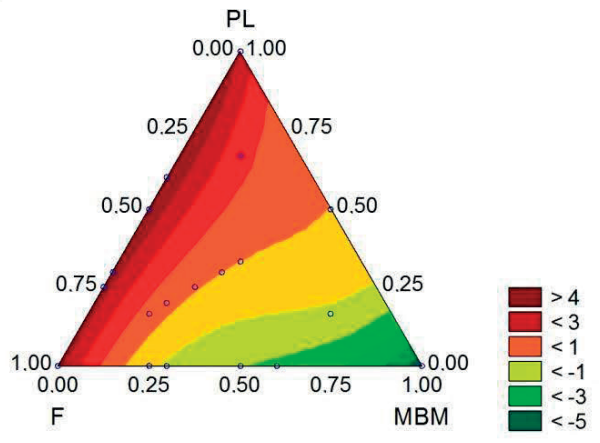

b)

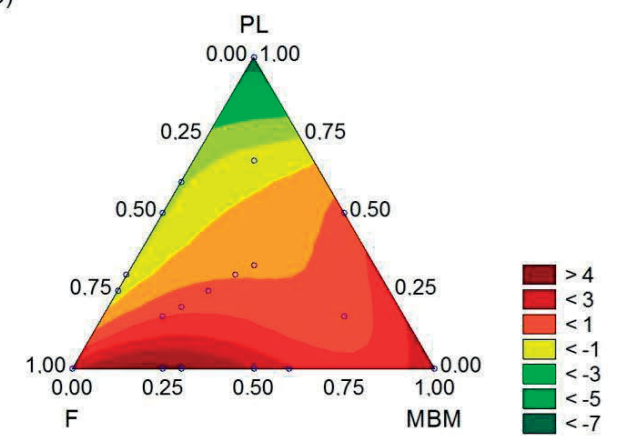

d)

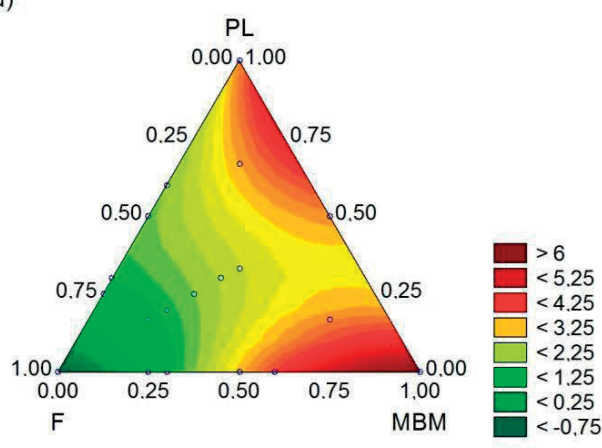

Fig. 1. Graphical presentation of the function tested object: a) the calorific value, b) content of Pc (total phosphorus content), c) content of $\mathrm{K}, \mathrm{d}$ ) content of $\mathrm{Ca}, \mathrm{e})$ content of $\mathrm{Mg}$

Basing on model parameters, an approximation profile was obtained which is shown in Figure 2. Mixture $(40 \%$ of feathers, $25 \%$ of MBM and 35\% of poultry litter) is characterized by the combustion heat equal to $13.3 \mathrm{kJg}^{-1}$, and the ash after its combustion contains: $11.98 \%$ of phosphorus $\left(\mathrm{P}_{2} \mathrm{O}_{5} 27.45 \%\right), 5.23 \%$ of potassium $\left(6.30 \% \mathrm{~K}_{2} \mathrm{O}\right)$, $32.66 \%$ of calcium ( $\mathrm{CaO} 45.69 \%$ ) and $2.25 \%$ of magnesium (3.73\% $\mathrm{MgO}$ ). Moreover, the ash contains $0.45 \%$ of iron, $0.02 \%$ of copper, $0.10 \%$ of manganese and $0.11 \%$ of zinc.

Reducing the amount of feathers in a mixture of $10 \%$ and increasing the fraction of poultry litter ( $40 \%$ of feather, $25 \%$ of MBM and $35 \%$ of poultry litter) resulted, the reduction of phosphorus content (about $3 \%$ of $\mathrm{P}_{2} \mathrm{O}_{5}$ ) and a simultaneous increase in the potassium $\left(0.35 \% \mathrm{~K}_{2} \mathrm{O}\right)$, magnesium $(0.3 \% \mathrm{MgO})$ and calcium ( $\left.\mathrm{CaO} 1.13 \%\right)$ content, which agreed with previous findings.

Using a mixture having a composition of $40 \% \mathrm{~F}, 20 \%$ of $\mathrm{MBM}$ and $40 \%$ of $\mathrm{PL}$, calorific value is $13.1 \mathrm{kJg}^{-1}$. Ashes after combustion contain: $11.33 \%$ of phosphorus $\left(25.96 \% \mathrm{P}_{2} \mathrm{O}_{5}\right)$ 5.67\% potassium $\left(6.83 \% \mathrm{~K}_{2} \mathrm{O}\right), 32.69 \%$ of calcium $(45.73 \% \mathrm{CaO})$ and $2.51 \%$ magnesium $(4.16 \% \mathrm{MgO})$. They also contain $0.46 \%$ of iron, $0.02 \%$ of copper, $0.11 \%$ of manganese and $0.11 \%$ of zinc.

Using the $40 \%$ content of feathers in the mixture and reducing the content of MBM from $25 \%$ to $20 \%$ and increasing the fraction of poultry litter from 35 to $40 \%$ gives a mixture of reduced phosphorus content (about $4.7 \% \mathrm{P}_{2} \mathrm{O}_{5}$ ), high calcium (more than $1 \% \mathrm{CaO}$ ), potassium (about $0.9 \% \mathrm{~K}_{2} \mathrm{O}$ ), and magnesium $(0.73 \% \mathrm{MgO}$ ) content. 

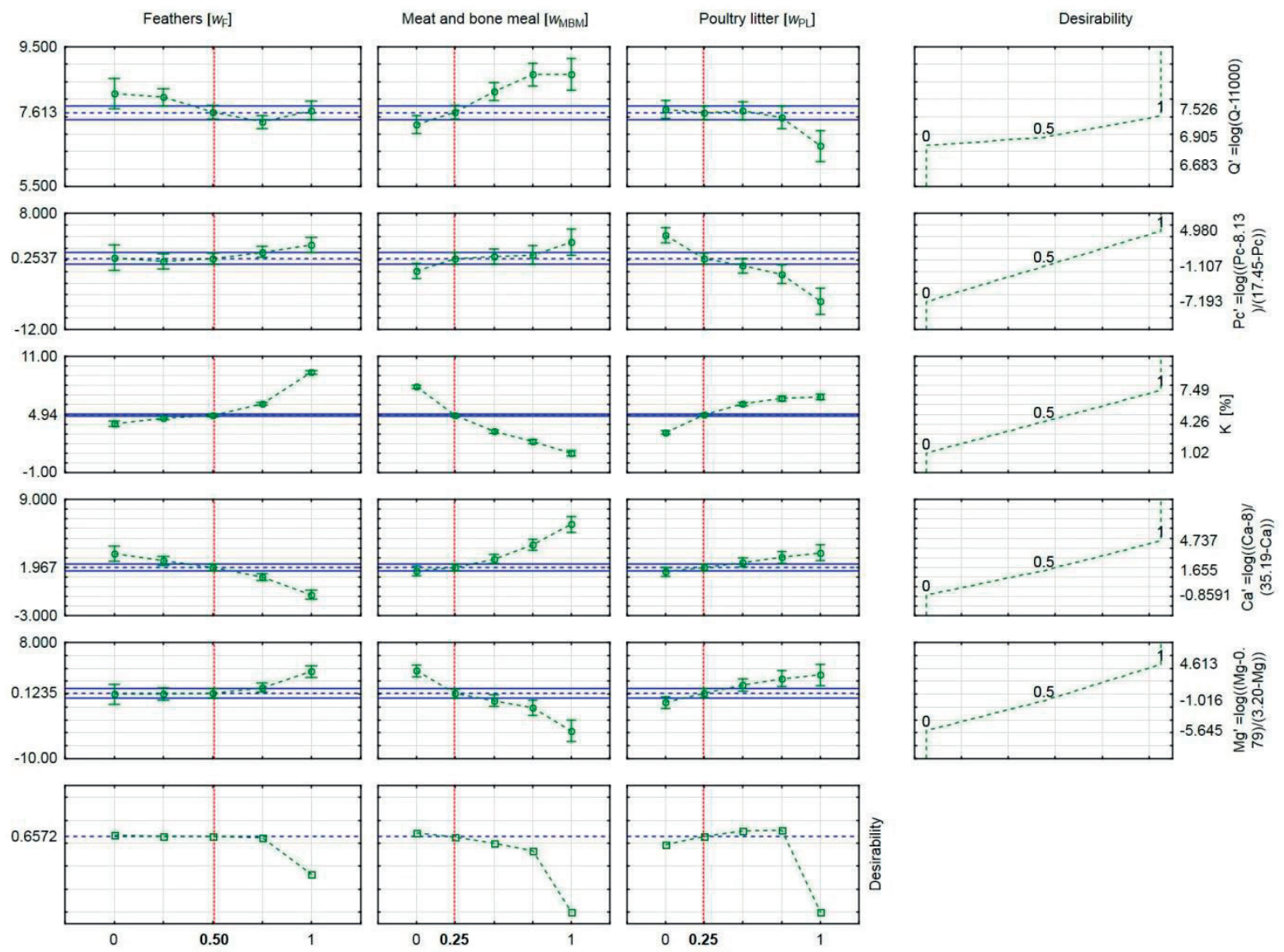

Fig. 2. Approximation profile with the utility function for the mixture F:MBM:PL - 0.50:0.25:0.25

\section{Discussion}

Calorific value increases with increasing mass fraction of meat-bone meal. This is due to the fact that meat-bone meal (because of their organic origin) has the highest heat of combustion (Conesa et al. 2005). A high content of phosphorus in ash is observed with a smaller share of poultry litter in the mixture (due to low P content of poultry litter compared to feathers and MBM). Ash after combustion of meat-bone meal contains nearly exclusively hydroxyapatite, which consists in a significant amount of phosphorus and calcium (Fryda et al. 2007). For this reason, meat-bone meal is a rich source of these macronutrients. Brod et al. (2016) reported that phosphorus from hydroxyapatite and chlorfluorapatite has low solubility, especially in soils with $\mathrm{pH}>6.5$.

Calcium in the ash also origins from poultry litter, it is in the form of calcium carbonate and calcium oxide. In the ash after combustion of poultry litter and feathers, a high level of potassium and magnesium is observed (Kelleher et al. 2002, Abelha et al. 2003). Poultry litter and waste feathers can be used as a major source of these elements.

Ash after thermal conversion of the mixtures of feathers - MBM - poultry litter has a composition of macro- and micronutrients composition comparable with of calcium and phosphorus-potassium fertilizers, and phosphorus present is characterized by high absorption by plants. In case of using the ashes for fertilizers, an important parameter is not only the amount of nutrients in ashes but also theirs solubility in a soil which determines plant-availability. Previous studies (Staron et al. 2016) have shown that the solubility of phosphorus in citric acid varies from about 40 to more than $90 \%$ and depends on the type of waste and the combustion temperature of those waste.

MBM is a material which composition depends on the raw material used. However, it always contains significant volatiles and ash content rich in alkali and alkaline earth metals. Besides calcium and phosphorus there is also chlorine. In MBM combustion and co-combustion studies, the severe corrosion and fouling problems were attributed to chlorine. The use of chicken manure as an additional ingredient that contains significant amounts of Ca causes the melting temperature to change to a higher level, thereby decreasing the sintering and agglomeration problems that arise from the combination of $\mathrm{K}, \mathrm{Cl}, \mathrm{P}$ with $\mathrm{Si}$ and $\mathrm{S}$. This problem occurs in the case of i.a. use of straw as a fuel for co-incineration (Fryda et al. 2006). During research conducted by McDonnell et al. (2001) it 
was found that co-combustion of MBM in pelletised form with some peat reduced the associated with the fuel volatility. Olofsson et al. (2002) observed a reduction of NO and NOx emissions by adding MBM to coal because of its high volatile content.

\section{Conclusion}

Calorific value of obtained granules from feathers, meat-bone meal and poultry litter can be used as an alternative source of energy. In addition, ash after combustion is a rich source of calcium, phosphorus and potassium and has a high content of trace elements ( $\mathrm{Zn}, \mathrm{Cu}, \mathrm{Mn}$, and Fe). Therefore, they may be used as additives for fertilizers and soil improvers in order to improve the physical and chemical properties of the soil. The nutrient content in the ash obtained from the plants is similar to that of the phosphorus-potassium fertilizers offered for sale. However, the solubility of nutrients in ashes it varies according to the type of waste from which the ash was formed and the $\mathrm{pH}$ of the soil. The ash formed as a result of controlled burning is also safe in terms of sanitation, which is a basic requirement for the waste and animal by-products used for commercial purposes.

\section{References}

Abelha, P., Gulyurtlu, I., Boavida, D., Barros, J.S., Cabrita, I., Leahy, J., Kelleher, B. \& Leahy, M. 2003. Combustion of poultry litter in a fluidised bed combustor. Fuel 82: 687-692. https://doi.org/10.1016/S0016-2361(02)00317-4

Badri, B.B., Apan, A.A. \& Raine, S.R. 2002. Geographic information system based manure application plan. Journal of Environmental Management 64: 99-113. https://doi.org/10.1006/jema.2001.0484

Brod, E., Øgaard, A.F., Krogstad, T., Haraldsen, T.K., Frossard E. \& Oberson, A. 2016. Drivers of Phosphorus Uptake by Barley Following Secondary Resource Application. Frontiers in Nutrition 3. https://doi.org/10.3389/fnut.2016.00012

Conesa, J.A., Fullana, A. \& Font, R. 2005. Dioxin production during the thermal treatment of meat and bone meal residues. Chemosphere 59: 85-90. https://doi.org/10.1016/j.chemosphere.2004.09.089

Costa, J.C., Barbosa, S.G. \& Sousa, D.Z. 2012. Effects of pre-treatment and bioaugmentation strategies on the anaerobic digestion of chicken feathers. Bioresource Technology 120: 114-119. https://doi.org/10.1016/j.biortech.2012.06.047

EC 2009. Regulation (EC) No. 1069/2009 of the European Parliament and of the Council laying down health rules as regards animal by-products and derived products not intended for human consumption and repealing Regulation (EC) No. 1774/2002 (Animal by-products Regulation). Official Journal of the European Union L 300:1-33.

Eurostat 2016. Agricultural production - animals. http://ec.europa.eu/eurostat/statistics-explained/index.php/Agricultural_production_-_animals. Accessed 5 January 2016.

Fryda, L., Panopoulos, K., Vourliotis, P., Kakaras, E. \& Pavlidou, E. 2007. Meat and bone meal as secondary fuel in fluidized bed combustion. Proceedings of the Combustion Institute 31: 2829-2837. https://doi.org/10.1016/j.proci.2006.07.151

Fryda, L., Panopoulos, K., Vourliotis, P., Pavlidou, E. \& Kakaras, E. 2006. Experimental investigation of fluidised bed co-combustion of meat and bone meal with coals and olive bagasse. Fuel 85: 1685-1699. https://doi.org/10.1016/j.fuel.2006.01.020

Górecki, H., Górecka, H., Chojnacka, K., Dobrzański, Z., Artmańska, M., Barańska, M. \& Biegańska, S. 2010. Utilization of poultry wastes to multicomponent fertilizers. Przemys/ Chemiczny 89: 360-365.

Grazziotin, A., Pimentel, F.A., de Jong, E.V. \& Brandelli, A. 2006. Nutritional improvement of feather protein by treatment with microbial keratinase. Animal Feed Science and Technology 126: 135-144. https://doi.org/10.1016/j.anifeedsci.2005.06.002

Hussein, M.S., Burra, K.G., Amano, R.S. \& Gupta A.K. 2017. Temperature and gasifying media effects on chicken manure pyrolysis and gasification. Fuel 202: 36-45. https://doi.org/10.1016/j.fuel.2017.04.017

Junga, R., Knauer, W., Niemiec, P. \& Tańczuk, M. 2017. Experimental tests of co-combustion of laying hens manure with coal by using thermogravimetric analysis. Renewable Energy 111: 245-255. https://doi.org/10.1016/j.renene.2017.03.099

Kelleher, B.P., Leahy, J.J., Henihan, A.M., O’Dwyer, T.F., Sutton, D. \& Leahy, M.J. 2002. Advances in poultry litter disposal technology - a review. Bioresource Technology 83: 27-36. https://doi.org/10.1016/S0960-8524(01)00133-X

Kim, J.M., Lim, W.J. \& Suh, H.J. 2001. Feather-degrading Bacillus species from poultry waste. Process Biochemistry 37: $287-291$. https://doi.org/10.1016/S0032-9592(01)00206-0

Korniłłowicz-Kowalska, T. \& Bohacz, J. 2010. Dynamics of growth and succession of bacterial and fungal communities during composting of feather waste. Bioresource Technology 101: 1268-1276. https://doi.org/10.1016/j.biortech.2009.09.053

Kwiatkowski, K., Krzysztoforski, J., Bajer, K. \& Dudyński, M. 2013. Bioenergy from feathers gasification - Efficiency and performance analysis. Biomass and Bioenergy 59: 402-411. https://doi.org/10.1016/j.biombioe.2013.07.013

Martinez-Hernandez, A.L., Velasco-Santos, C., de-Icaza, M. \& Castano, V.M. 2007. Dynamical-mechanical and thermal analysis of polymeric composites reinforced with keratin biofibers from chicken feathers. Composites Part B: Engineering 38: 405-410. https://doi.org/10.1016/j.compositesb.2006.06.013

Mazerski, J. 2000. Podstawy chemometrii. Gdańsk: Gdansk University of Technology Publisher. 141 p.

McDonnell, K., Desmond, J., Leahy, J.J., Howard-Hildige, R. \& Ward, S. 2001. Behaviour of meat and bonemeal/peat pellets in a bench scale fluidised bed combustor. Energy 26: 81-90. https://doi.org/10.1016/S0360-5442(00)00048-7 
Moutinho, S., Martínez-Llorens, S., Tomás-Vidal, A., Jover-Cerdá, M., Oliva-Teles, A. \& Peres, H. 2017. Meat and bone meal as partial replacement for fish meal in diets for gilthead seabream (Sparus aurata) juveniles: Growth, feed efficiency, amino acid utilization, and economic efficiency. Aquaculture 468: 271-277. https://doi.org/10.1016/j.aquaculture.2016.10.024

Olofsson, G., Wang, W., Ye, Z., Bjerle, I. \& Andersson, A. 2002. Repressing NOx and N 2 O Emissions in a Fluidized Bed Biomass Combustor. Energy Fuels 16: 915-919. https://doi.org/10.1021/ef0102768

Paul, T., Halder, S.K., Das, A., Bera, S., Maity, C., Mandal, A., Das, P.S., Das Mohapatra, P.K., Pati, B.R. \& Mondal, K.C. 2013. Exploitation of chicken feather waste as a plant growth promoting agent using keratinase producing novel isolate Paenibacillus woosongensis TKB2. Biocatalysis and Agricultural Biotechnology 2: 50-57. https://doi.org/10.1016/j.bcab.2012.10.001

Polish Norm 1981. PN-81/G-04513: Solid fuels - Determination of heat of combustion and calculation of calorific value.

Polish Norm 1988. PN-88/C-87015: Fertilizers - Methods of test quantities of phosphates.

Schröder, J. 2005. Revisiting the agronomic benefits of manure: a correct assessment and exploitation of its fertilizer value spares the environment. Bioresource Technology 96: 253-261. https://doi.org/10.1016/j.biortech.2004.05.015

Skodras, G., Grammelis, P. \& Basinas, P. 2007. Pyrolysis and combustion behaviour of coal-MBM blends. Bioresource Technology 98: 1-8. https://doi.org/10.1016/j.biortech.2005.12.007

Staroń, P., Banach, M. \& Kowalski, Z. 2013. Assessment of an application of ashes produced by incineration of poultry industry waste as a rich phosphorus source. Przemysl Chemiczny 92: 1142-1144.

Staroń, P., Kowalski, Z., Staroń, A., Seidlerová J. \& Banach, M. 2016. Residues from the thermal conversion of waste from the meat industry as a source of valuable macro- and micronutrients. Waste management 49: 337-345.

StatSoft, Inc. 2013. Electronic Statistics Textbook. Tulsa, OK: StatSoft. http://www.statsoft.com/textbook/. Accessed 25 January 2016.

Suntornsuk, W. \& Suntornsuk, L. 2003. Feather degradation by Bacillus sp. FK 46 in submerged cultivation. Bioresource Technology 86: 239-243. https://doi.org/10.1016/S0960-8524(02)00177-3

Vasileva-Tonkova, E., Gousterova, A. \& Neshev, G. 2009. Ecologically safe method for improved feather wastes biodegradation. International Biodeterioration \& Biodegradation 63: 1008-1012. https://doi.org/10.1016/j.ibiod.2009.07.003

Zaghloul, T.I., Embaby, A.M. \& Elmahdy, A.R. 2011. Biodegradation of chicken feathers waste directed by Bacillus subtilis recombinant cells: Scaling up in a laboratory scale fermentor. Bioresource Technology 102: 2387-2388. https://doi.org/10.1016/j. biortech.2010.10.106 